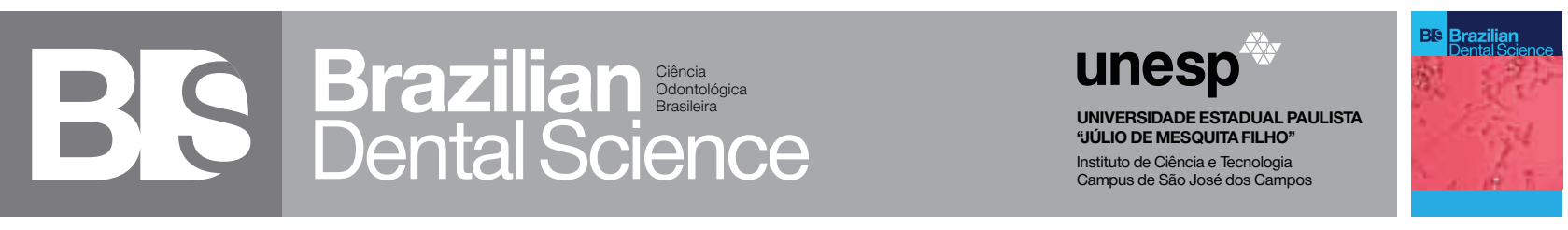

\title{
Multidisciplinary approach for crown-root fracture treatment after trauma: case report
}

Abordagem multidisciplinar para tratamento de fratura corono-radicular pós-traumatismo: relato de caso

\author{
Gisele Cristina Galdeano ANDRIOLO ${ }^{1}$, Denise PEDRINI ${ }^{2}$, Elizane Ferreira HAMANAKA ${ }^{1}$, Eloá Rodrigues LUVIZUTO ${ }^{2}$, Sônia Regina \\ PANZARINI $^{2}$, Celso Koogi SONODA ${ }^{2}$ \\ 1 - UNESP - Univ Estadual Paulista - School of Dentistry of Araçatuba - Araçatuba - SP - Brazil. \\ 2 - UNESP - Univ Estadual Paulista - School of Dentistry of Araçatuba - Department of Surgery and Integrated Clinic - Araçatuba - SP - Brazil.
}

\section{ABSTRACT}

The development of an accurate diagnosis and appropriate treatment plan can be a complex task, especially in cases of dentoalveolar trauma. The authors present a case report of crown-root fracture caused by trauma and highlight the importance of a multidisciplinary approach for the treatment. An eighteen year-old boy had a bicycle accident resulting in dental trauma. The upper right first molar showed a complicated crownroot fracture and the lower left second pre-molar showed an uncomplicated crown-root fracture. Endodontic treatment, controlled tooth extrusion, periodontal surgery for recovery of biological width, and porcelain crown and onlay restorations were performed. Esthetic and functional results were achieved. At the two-year follow-up it was observed that the tooth/onlay interface of the upper right first molar was stained and the onlay of the left lower second pre-molar was fractured. Therefore, the interface stained was repaired and a porcelain crown was made for the lower second premolar. The clinical case presented herein leads to the conclusion that a multidisciplinary treatment plan is extremely important for a proper resolution in cases of dentoalveolar trauma.

\section{KEYWORDS}

Crown-root fracture; Permanent tooth; Tooth injuries.

\section{RESUMO}

A elaboração de um diagnóstico preciso e de um plano de tratamento adequado pode constituir uma tarefa bastante complexa, especialmente nos casos de traumatismos dentoalveolares. O relato de caso teve por finalidade demonstrar a importância da abordagem multidisciplinar para o tratamento de fratura corono-radicular pós-traumatismo. Paciente de 18 anos de idade, gênero masculino, sofreu uma queda de bicicleta resultando em traumatismos dentários. O 16 sofreu fratura corono-radicular complicada e o 35 fratura corono-radicular não-complicada. Foi realizado tratamento endodôntico, extrusão dentária controlada, cirurgia periodontal para recuperação do espaço biológico, coroa de porcelana e restauração tipo onlay. O resultado estético e funcional foi alcançado. O paciente foi acompanhado por 2 anos onde foi observado um manchamento na interface dente/onlay do $16 \mathrm{e}$ fratura da onlay do 35 . Foi realizado um reparo na interface do 16 e confeccionada uma coroa de porcelana para o 35 . Foi possível concluir que a multidisciplinaridade do plano de tratamento é de extrema importância para uma adequada resolução dos casos de traumatismos dentoalveolares.

\section{PALAVRAS-CHAVE}

Fratura corono-radicular; Dentes permanentes; Traumatismos dentários. 


\section{LITERATURE REVIEW}

Crown fractures comprise the most 4 frequent injuries in the permanent dentition (26-76\% of dental injuries), while crown-root fractures comprise only 0.3 to $5 \%$ [1,2]. Dentoalveolar trauma presents epidemiological expression and becomes a public health problem due to the high incidence of physical violence, bicycle accidents, car accidents, falls, children's games, domestic violence, and the increasing popularity of extreme sports $[1,3,4]$.

Dental traumatic injuries involve function and esthetics damage, ranging from minor loss of enamel to complex fractures involving pulp tissue. Technical knowledge and clinical experience are essential to establish an accurate diagnosis and provide appropriate treatment plan [5]. Most of these types of fracture require a multidisciplinary approach and the treatment of choice will depend on a number of factors such as: length of fracture $[2,3,6-8]$, biological width invasion $[2,5,9,10]$, presence of pulp exposure, stage of root development [2,5-8,11,12], soft tissue injuries $[3,7,12,13]$, presence of concomitant periodontal trauma $[3,7,8]$, presence / absence of fractured fragment and its adaptation, occlusion, esthetics, time, and available resources [2,8-11,14-17].

There are several strategies in the literature for the treatment of esthetic and functional rehabilitation of crown and crownroot fractures: temporary or permanent use and maintenance of tooth fragment [2,8$11,14,15,17]$, orthodontic extrusion or periodontal surgery for recovery of biological width followed by direct resin restoration or prosthetic rehabilitation $[3,7,10,16,19,20]$, and extraction followed by dental implant or conventional prosthesis installation $[3,7]$.

Thus, this paper aims to present a clinical case of complicated and uncomplicated crownroot fractures treated with a multidisciplinary approach.

\section{DESCRIPTION OF CASE}

An eighteen year-old boy had dental injuries after a bicycle accident and had drawn attention at the Dentoalveolar Trauma Clinic at the Araçatuba Dental School - UNESP, complaining of pain at the upper right first molar. A chin laceration already sutured was observed at the extra-oral examination. Clinical and radiographic examination were observed: enamel crack on tooth 31 ; enamel fracture on teeth $13,14,15,21,23,24,26$ and 36 ; complicated crown-root fracture (with pulp involvement) on tooth 16 (Figure 1 - A and B) and uncomplicated crown-root fracture (without pulp involvement) on tooth 35 which was not observed on initial radiographs (Figure $2-\mathrm{A}$ and $\mathrm{B}$ ).
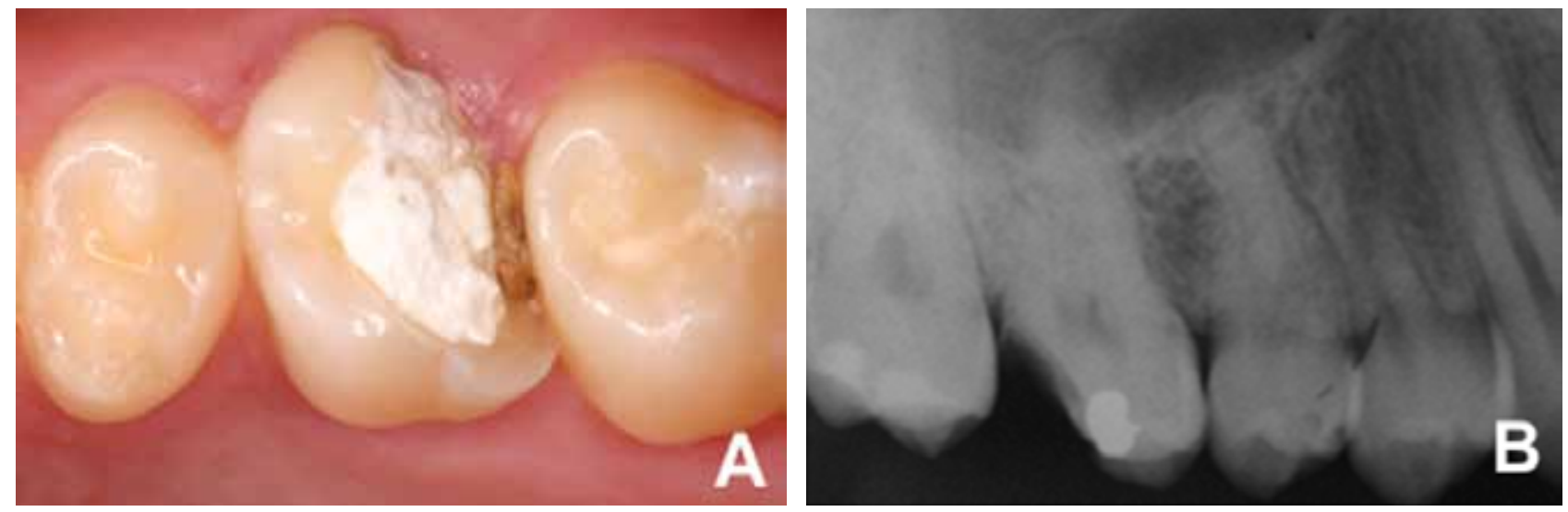

Figure 1- Initial clinical and radiographic examination of tooth 16. A - Radiographic image of the crown-root fracture. B-Radiographic image. 

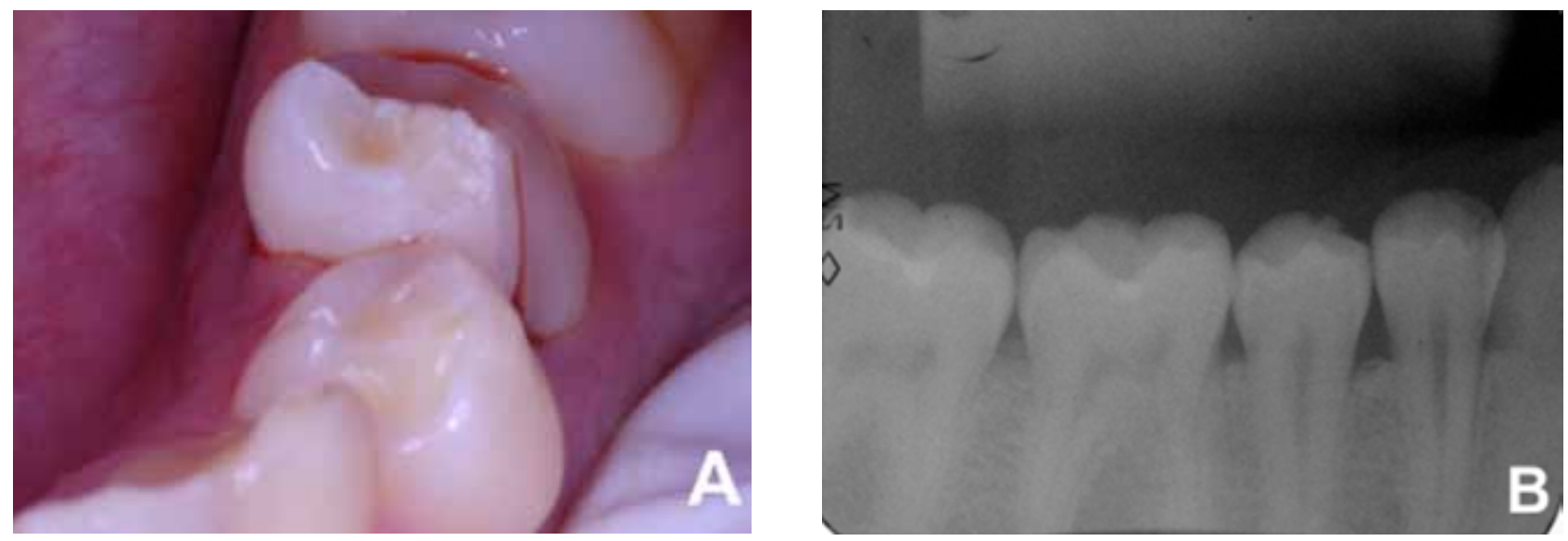

Figure 2 - Initial clinical and radiographic examination of tooth 35. A - Clinical aspect of the fragment slightly shifted. B - Radiographic image.

Endodontic treatment of tooth 16 was initiated and calcium hydroxide root canal dressing was conducted. The fragment of tooth 35 was removed (Figure 3) and a protection with glass ionomer cement (Fuji II LC, GC Corporation, Hasunuma-cho, Itabashi$\mathrm{ku}$, Tokyo, Japan) of the exposed dentin was performed. Fixed orthodontic appliance with brackets between tooth 35 and tooth 45 and single pipe on tooth 36 and tooth 46 (Figure 4A) was mounted in order to extrude tooth 35 to restore biological width. Occlusal wear of tooth 35 was performed every 21 days to allow space for tooth extrusion (Figure 4B). Total time required was six months: three months of activation and three months of containment.

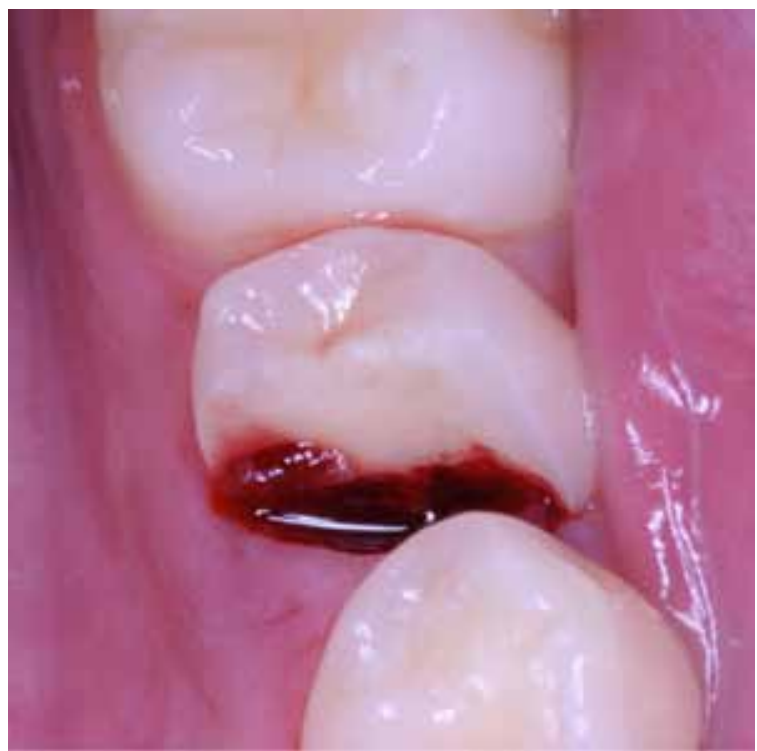

Figure 3 - Removal of fragment of tooth 35.
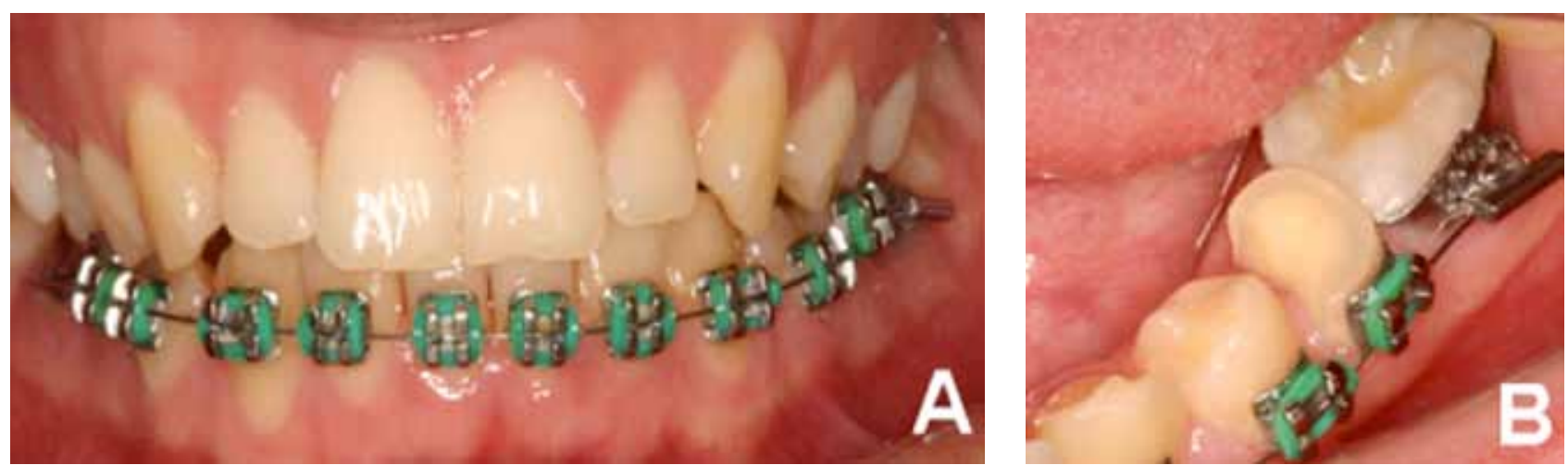

Figure 4 - Orthodontic extrusion of tooth 35. A - Orthodontic device with fixed brackets in the lower arch. B - Oclusal crown abraded. 
Root canal filling with calcium hydroxide cement (Sealapex, Kerr Corporation, Orange, California, USA) and gutta-percha (Tanari Industrial Ltda, Manaus, Amazonas, Brazil) by lateral condensation technique was held 14 days after the placement of intracanal dressing on tooth 16 . The crown was temporarily restored with glass ionomer (Vidrion R, SS White, Rio de Janeiro, RJ, Brazil) and an interdental elastic wedge was placed on the distal surface (Figure 5A), in order to reestablish the interdental contact point. The interdental elastic wedge was removed after 1 week and another temporary restoration was performed to fill the interdental space gained followed by a periodontal surgery to recover biological width (Figure 5B). After 60 days, a ceromer indirect restoration was fabricated (Epricord, Kuraray Medical Inc., Tokyo, Japan).

Endodontic treatment of tooth 35 was held after recovery of the biological width through orthodontic extrusion. Since gingival margin follow tooth extrusion during
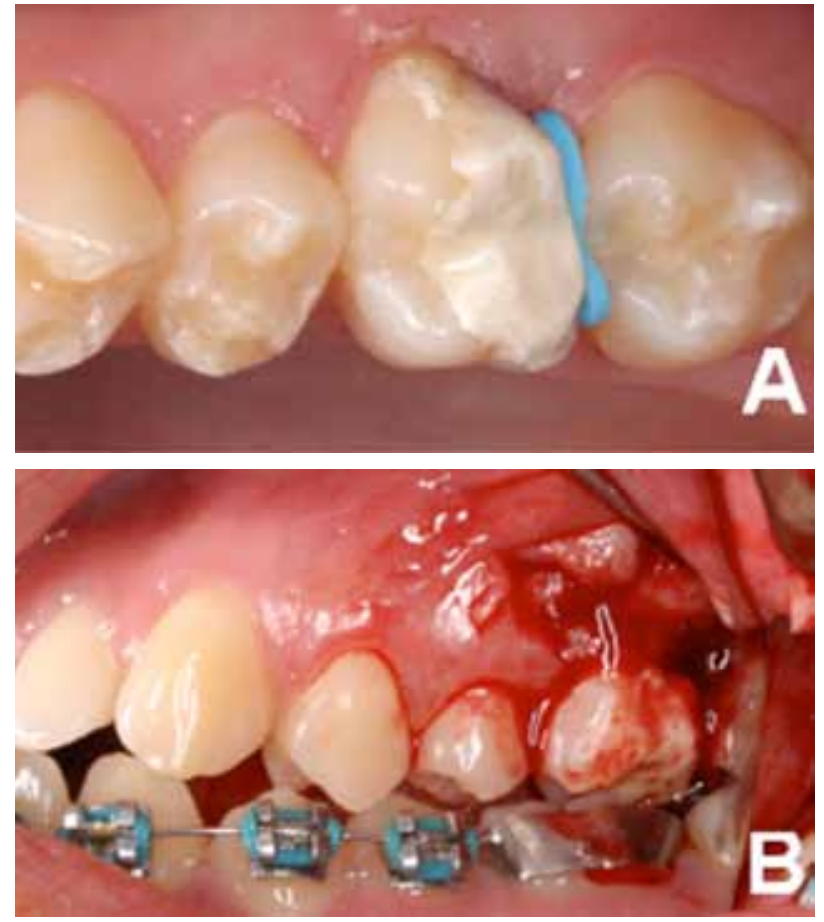

Figure 5 - A - Temporary restoration and interdental elastic wedge on tooth 16. B - Periodontal surgery to recover biological width. orthodontic extrusion, the gingival flap was apically positioned to properly recover the gingiva (Figure 6). Ceromer indirect onlay (Epricord, Kuraray Medical Inc., Tokyo, Japan) was performed after gingival healing.

Clinical and radiographic follow-up of tooth 31 was performed due to the presence of an enamel crack. Tooth 13 and 23 showed small enamel fractures, which had esthetic and function restored by polishing. The remaining teeth with enamel fractures were restored with light-cured composite resin (TPH, Dentsply Ind. e Com. Ltda, Brazil).

Clinical (Figure $7-\mathrm{A}$ and $\mathrm{B}$ ) and radiographic (Figure $8-A$ and $B$ ) evaluations at 2-year follow-up appointment were performed. It was observed that the tooth/ onlay interface of the right upper first molar was stained (Figure 7A) and the onlay of thelower left second pre-molar was fractured (Figure 7B). So, the interface stained was repaired (Figure 9A) and a porcelain crown was made for the lower second pre-molar (Figure 9B).

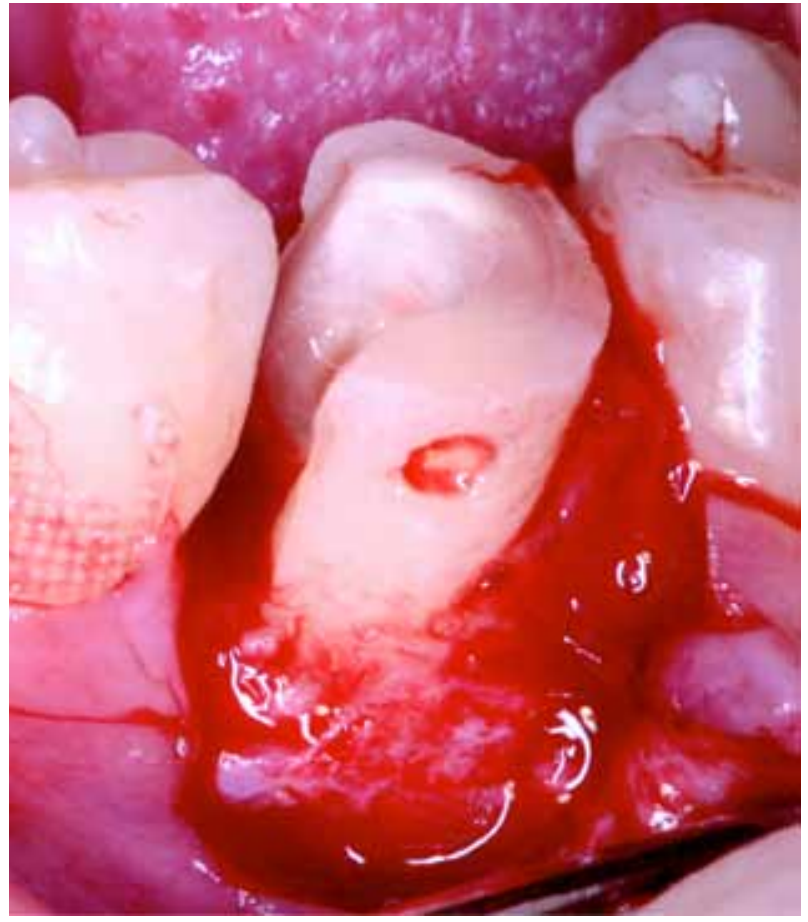

Figure 6 - Apically positioned gingival flap of tooth 35. 

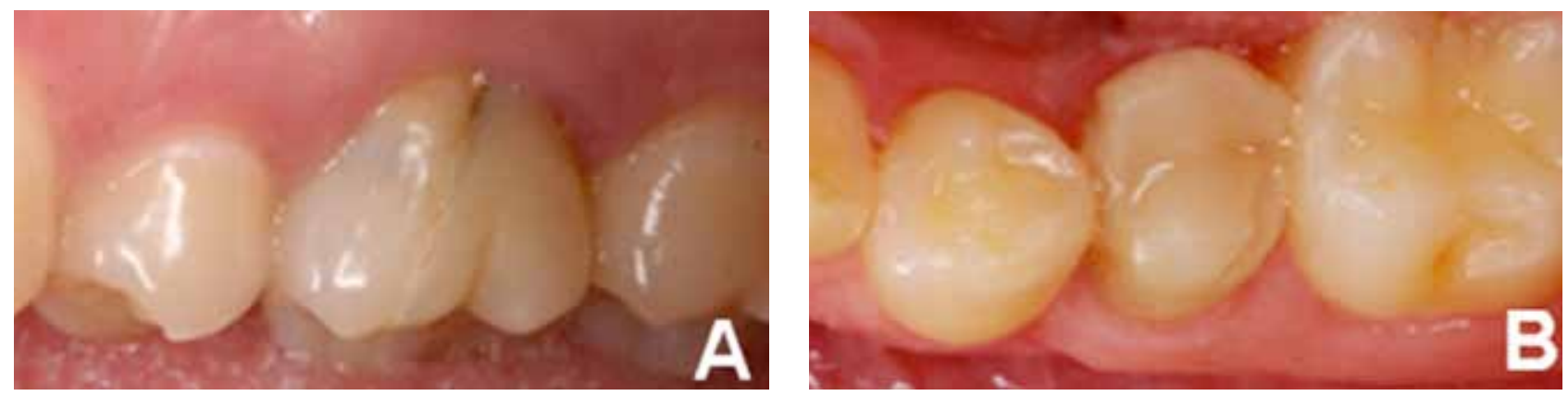

Figure 7- Clinical two years follow-up of tooth 16 (A) and 35 (B).
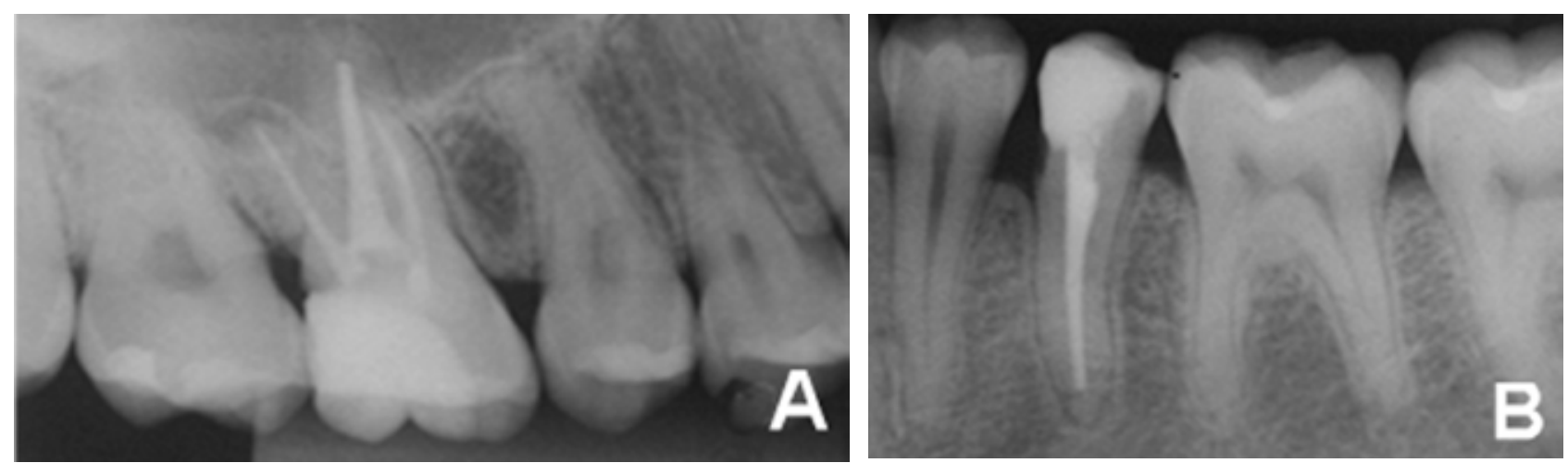

Figure 8- Radiographic two years follow-up of tooth 16 (A) and 35 (B).
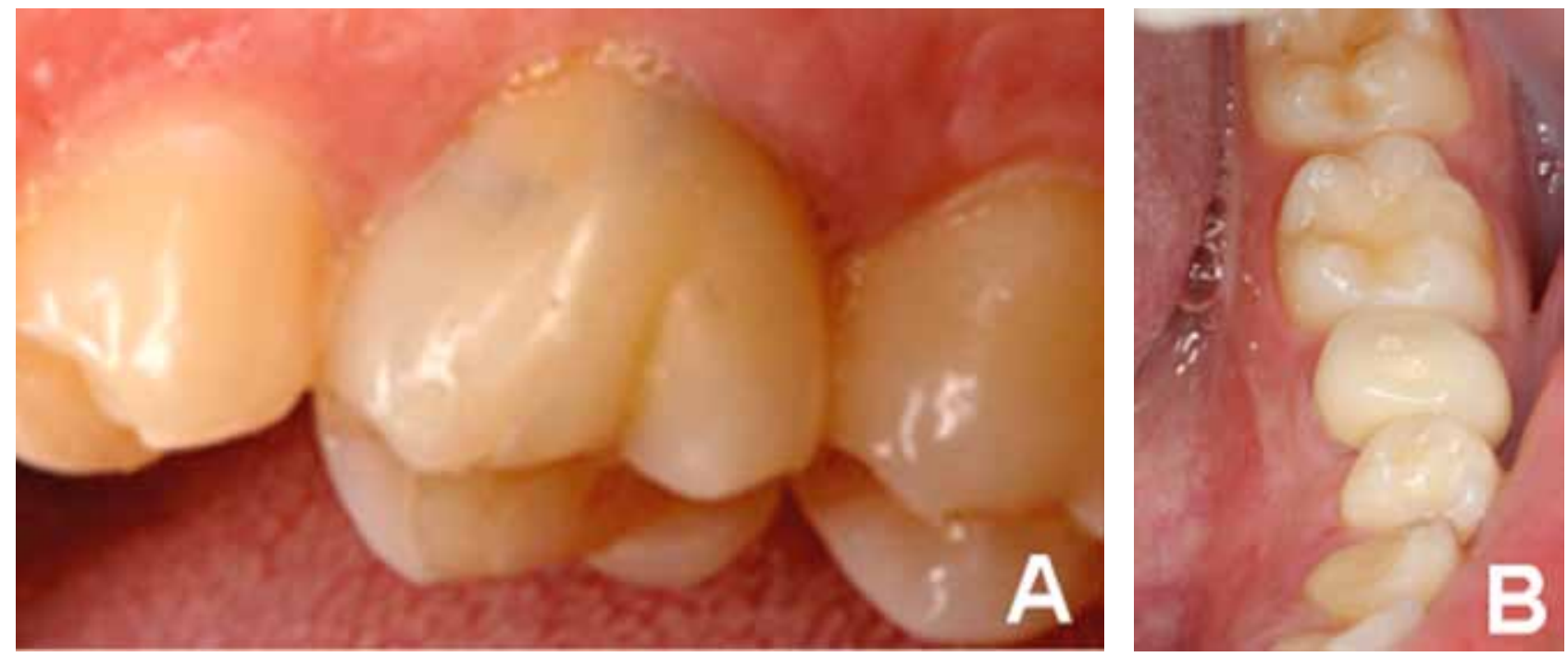

Figure 9 - Final clinical aspects of teeth 16 (A) and 35 (B). 


\section{DISCUSSION}

Teeth and supporting dental tissues can be traumatized in different ways. Although the incidence of dental trauma has reached epidemiological levels in recent years, its treatment still raises questions among professionals. The esthetic and functional recovery is a challenge in most cases and dentists should be well prepared to provide the best possible treatment without additional damage [5].

Fractures that invade the biological width, especially if invasion is located at the buccal and/or proximal regions and extending apically to the bone crest, are the most difficult to solve and, bonding the fragment is rarely a viable treatment [21]. In the present clinical case, tooth extrusion required occlusal wear in order to obtain occlusal space during extrusive movement and therefore, the tooth fragment was unsuitable.

Both teeth 16 and 35 had the invasion of biological width in at least one of their surfaces. Chronic inflammatory response occurs when teeth are restored without reestablishing the biologic width. Crest bone resorption with apical migration of connective tissue and junctional epithelium is also observed histologically. The consequences of the invasion of the biological width include gingival inflammation that persists even in the presence of an adequate plaque control, gingival pain and sensitivity to mechanical stimuli, gingival recession and/or periodontal pocket formation [21]. Moreover, when the fracture margin is exposed, clinical procedures can be performed with strict control of moisture and bleeding, optimizing the predictability of restorative treatment [19].

In such cases, the clinician should consider a few factors for selecting the best possible approach: subgingival lesion extension, lesion morphology, crown/root proportion, tooth position in the arch, prognosis of restorative treatment, esthetic and phonetic considerations, occlusal factors, location of furcation, root morphology and anatomy, endodontic considerations and treatment costs / benefits $[19,21]$.
Orthodontic extrusion was the treatment chosen for the recovery of biological width of the uncomplicated crown-root fracture tooth. This treatment option may be considered more conservative to the esthetic [21] and organic [19] point of view, compared to resective surgery [21]. Before deciding on this treatment, the practitioner should be aware of some factors that affect final result such as bone root insertion and dentin thickness $[3,9]$. During orthodontic extrusion of tooth 35 , the occlusal portion of the crown needed to be abraded resulting to pulp exposure. Therefore, endodontic treatment was performed.

Resective surgery is the most commonly used approach for posterior teeth due to greater bone support, greater root surface area, flat interproximal form, and less esthetic requirement. Another factor to be considered is the prominence of molar roots, and the intercuspal unfavorable axial position of the posterior teeth, which can affect the extrusion of these teeth. Another problem is that the beginning of the furcation can be at the level of the cementoenamel junction of the adjacent teeth, and if it is necessary to regularize bone architecture with osteotomy, furcation exposure might occur [21]. As tooth 16 showed biological width invasion only at the distal surface, the surgical procedure was opted.

The extraction procedure is a treatment only performed if all other treatments are not indicated. But, the clinician should be aware of the fact that the future prosthetic rehabilitation is considerably complicated if bone is lost with time $[3,9]$.

Bonding dental fragment is a conservative treatment option when the tooth fragment is available. It reestablishes the form, contour, surface texture, color and alignment of the original tooth, and it is a simple and fast treatment. This treatment option leads to a positive emotional and social response of patients due to the maintenance of the natural tooth structure $[11,22]$. However, there are limitations as there is the possibility that the fragment may not reacquire the original color of the remnant tooth, there is a risk of 
displacement of the fragment with increasing magnitude of the fracture and type of occlusion of the patient.

The need of crown resection in order to gain interocclusal space for tooth extrusion also modifies the original anatomy of the crown, not allowing the reattachment of fractured tooth fragment. Thus, the choice of prosthetic onlay constitutes appropriate indication for preserving the remaining coronary tissue. The prosthetic onlay also provides satisfactory cosmetic results. Masticatory and hygiene habits, which may change over time, might jeopardize the results. In this case presented herein, masticatory forces resulted in the necessity to perform a premolar full crown.

The clinical case reported herein demonstrates the importance of a multidisciplinary treatment plan for a proper resolution of dental trauma.

\section{REFERENCES}

1. Andreasen J0, Andreasen FM, Andersson L. Textbook and color atlas of traumatic injuries to the teeth. 4th ed. Oxford: Blackwell; 2007.

2. Olsburgh S, Jacoby T, Krejci I. Crown fractures in the permanent dentition: pulpal and restorative considerations. Dent Traumatol. 2002 Jun;18(3):103-15.

3. Elias $\mathrm{H}$, Baur DA. Management of trauma to supporting dental structures. Dent Clin North Am. 2009 0ct;53(4):675-89.

4. de Castro JC, Poi WR, Manfrin TM, Zina LG. Analysis of the crown fractures and crown-root fractures due to dental trauma assisted by the Integrated Clinic from 1992 to 2002. Dent Traumatol. 2005 Jun;21(3):121-6.

5. de Castro MA, Poi WR, de Castro JC, Panzarini SR, Sonoda CK, et al. Crown and crown-root fractures: an evaluation of the treatment plans for management proposed by 154 specialists in restorative dentistry. Dent Traumatol. 2010 Jun;26(3):236-42.

6. Moule AJ, Moule CA. Minor traumatic injuries to the permanent dentition. Dent Clin North Am. 2009 0ct;53(4):639-59.

7. Jaramillo DE, Bakland LK. Trauma kits for the dental office. Dent Clin North Am. 2009 0ct;53(4):751-60.
8. Trushkowsky RD. Esthetic, biologic and restorative considerations in coronal segment reattachment for a fractured tooth: a clinical report. J Prosthet Dent. 1998 Feb;79(2):115-9.

9. Wang J, Li M. Multidisciplinary treatment of a complicated crownroot fracture. Pediatr Dent. 2010 May-Jun;32(3):250-4.

10. Yilmaz Y, Zehir C, Eyuboglu 0, Belduz N. Evaluation of success in the reattachment of coronal fractures. Dent Traumatol. 2008 Apr;24(2):151-8.

11. Subramanian K, Chogle SM. Medical and orofacial considerations in traumatic dental injuries. Dent Clin North Am. 2009 0ct;53(4):61726.

12. Al-Jundi SH. The importance of soft tissue examination in traumatic dental injuries: a case report. Dent Traumatol. 2010 Dec;26(6):509-11.

13. Kina M, Ribeiro LG, Monteiro S, de Andrada MA. Fragment bonding of fractured anterior teeth: case report. Quintessence Int. 2010 Jun;41(6):459-61.

14. Saito CTMH, Guskuma MH, Gulinelli JL, Sonoda CK, Garcia-Júnior $\mathrm{IR}$, et al. Management of a complicated crown-root fracture using adhesive fragment reattachment and orthodontic extrusion. Dent Traumatol. 2009 0ct;25(5):541-4.

15. Andreasen FM, Norén JG, Andreasen JO, Engelhardtsen S, Lindh-Strömberg U. Long term survival of fragment bonding in the treatment of fractured crowns: a multicenter clinical study. Quintessence Int. 1995 0ct;26(10):669-81.

16. Zorba YO, Ozcan E. Reattachment of coronal fragment using fiberreinforced post: a case report. Eur J Dent. 2007 Jul;1(3):174-8.

17. Poi WR, Cardoso L de C, de Castro JC, Cintra LT, Gulinelli JL, et al. Multidisciplinary treatment approach for crown fracture and crown-root fracture - a case report. Dent Traumatol. 2007 Feb;23(1):51-5.

18. Koyuturk AE, Malkoc $S$. Orthodontic extrusion of subgingivally fractured incisor before restoration. A case report: 3-years followup. Dent Traumatol. 2005 Jun;21(3):174-8.

19. Bourguignon C, Sigurdsson A. Preventive strategies for traumatic dental injuries. Dent Clin North Am. 2009 0ct;53(4):729-49.

20. Maia EA, Baratieri LN, de Andrada MA, Monteiro S Jr, de Araújo EM $J$. Tooth fragment reattachment: fundamentals of the technique and two case reports. Quintessence Int. 2003 Feb;34(2):99-107.

21. Baratieri LN, Monteiro Júnior S, Cardoso AC, de Melo Filho JC. Coronal fracture with invasion of the biologic width: a case report. Quintessence Int. 1993 Feb;24(2):85-91.

22. Bourguignon C, Sigurdsson A. Preventive strategies for traumatic dental injuries. Dent Clin North Am. 2009 0ct:53(4):729-49.

\section{Sônia Regina Panzarini (Corresponding address)}

UNESP - Univ Estadual Paulista - Campus de Araçatuba Rua José Bonifácio, 1193 - Araçatuba - SP - Brasil

CEP: 16015-050

E-mail address: panzarin@foa.unesp.br 